\title{
Editorial
}

\section{Catalytic Concepts for Methane Combustion}

\author{
Sebastian Wohlrab * and Evgenii V. Kondratenko *
}

Leibniz-Institut für Katalyse e.V. an der Universität Rostock, Albert-Einstein-Str. 29a, 18059 Rostock, Germany

* Correspondence: sebastian.wohlrab@catalysis.de (S.W.); evgenii.kondratenko@catalysis.de (E.V.K.)

Citation: Wohlrab, S.; Kondratenko, E.V. Catalytic Concepts for Methane Combustion. Catalysts 2021, 11, 475. https://doi.org/10.3390/catal11040475

Received: 11 March 2021

Accepted: 18 March 2021

Published: 7 April 2021

Publisher's Note: MDPI stays neutral with regard to jurisdictional claims in published maps and institutional affiliations.

Copyright: (c) 2021 by the authors. Licensee MDPI, Basel, Switzerland. This article is an open access article distributed under the terms and conditions of the Creative Commons Attribution (CC BY) license (https:// creativecommons.org/licenses/by/ $4.0 /)$.
The release of methane from vehicles or/and stationary industrial sources must be reduced in order to control the emission of this greenhouse gas into the atmosphere. A suitable approach for this purpose is the catalytic oxidation of methane to carbon dioxide, with the latter product having a 28-times lower global warming potential. To this end, both academia and industry have focused on developing catalysts that operate at temperatures as low as possible. Some progress has already been achieved in this respect and a basic knowledge has been gained. However, it is mainly based on the results of tests carried out under ideal reaction conditions. Therefore, for application, it is essential to provide more advanced fundamentals that describe catalytic performance in a "real-world" environment. The focus of this Special Issue has been to identify studies that provide new insights into this exhaust catalysis. Catalysis under realistic conditions, understanding the role of exhaust components affecting catalyst activity, or promoting techniques that lower the combustion temperature are just a few examples of the current hot spots in this field and were specifically put in a new light in the five selected contributions.

Choya et al. [1] investigated the influence of undesirable impurities, specifically alkali metals and in this case $\mathrm{Na}^{+}$, which may remain in the catalyst after the synthesis of $\mathrm{Co}_{3} \mathrm{O}_{4}$ bulk catalysts. It has been shown that the sodium ions, which are still present in the catalyst, have a deteriorating effect on catalyst performance. This was attributed to the incorporation of $\mathrm{Na}^{+}$into the spinel lattice of the $\mathrm{Co}_{3} \mathrm{O}_{4}$ which is detrimental to the reducibility of this metal oxide. In addition to a thorough removal of alkali impurities, this work also provides evidence for possible activity loss due to contaminated exhaust gases.

In the recent past, small catalytic microcombustors have increasingly become the focus of methane utilization for energy purposes. Liu and co-workers [2] used a metal foam monolithic catalyst $\mathrm{Pd} / \mathrm{Al}_{2} \mathrm{O}_{3} / \mathrm{Fe}-\mathrm{Ni}$, which was placed in a quartz tube burner. In particular, this study was aimed at elucidating the effects of inlet velocity and equivalence ratio on catalytic combustion of methane. The authors also concluded from their work that detailed knowledge about the effects of impurities on catalyst deactivation is highly important for catalyst development.

Gerasimov et al. [3] established a structural change of the catalytically active phase. $\mathrm{La}_{0.5} \mathrm{Ca}_{0.5} \mathrm{Mn}_{0.5} \mathrm{Fe}_{0.5} \mathrm{O}_{3}$ in orthorhombic perovskite structure was partially converted to $\mathrm{Ca}_{1-x} \mathrm{Mn}_{x} \mathrm{O}$ during methane oxidation reaction in the temperature range of $300-600{ }^{\circ} \mathrm{C}$. This was shown by the formation of particles of this phase of about $10 \mathrm{~nm}$ on the surface of the perovskite.

AlMohamadi and Smith [4] reported the activity and stability of $\mathrm{PdO} / \gamma-\mathrm{AlOOH} / \gamma-$ $\mathrm{Al}_{2} \mathrm{O}_{3}$ monolith catalysts, which were promoted with different amounts of $\mathrm{CeO}_{2}$. These authors did not merely investigate the conversion of methane under ideal conditions but focused their work on a realistic application in which carbon monoxide or even sulfur compounds play a role in addition to water. Importantly, the addition of $\mathrm{CeO}_{2}$ can reduce catalyst deactivation. The authors proved this in a suitable experiment in the presence of 10 vol $\% \mathrm{H}_{2} \mathrm{O}$ and 5 ppmv $\mathrm{SO}_{2}$ at $500{ }^{\circ} \mathrm{C}$ over $25 \mathrm{~h}$ on stream.

For the determination of suitable catalysts, a high-throughput approach was chosen by Lenk et al. [5] to evaluate catalyst activity and to investigate interactions with pollutant gases or aging effects based on them. The complex interrelationships were recorded using 
the example of a combination of 3 at.\% $\mathrm{Pt} / \mathrm{Rh}$ with different amounts of $\mathrm{Al}, \mathrm{Mn}$ and Ce in the form of mixed oxides in a matrix of about two thousand different compositions. Using this high throughput approach, $\mathrm{Pt}_{3} \mathrm{Al}_{0} \mathrm{Mn}_{90} \mathrm{Ce}_{10}$ was identified as the best sample.

Funding: This research received no external funding.

Conflicts of Interest: The author declares no conflict of interest.

\section{References}

1. Choya, A.; De Rivas, B.; Gutiérrez-Ortiz, J.I.; López-Fonseca, R. Effect of Residual $\mathrm{Na}^{+}$on the Combustion of Methane over $\mathrm{Co}_{3} \mathrm{O}_{4}$ Bulk Catalysts Prepared by Precipitation. Catalysts 2018, 8, 427. [CrossRef]

2. Li, Y.; Luo, C.; Liu, Z.; Lin, F. Experimental Study on Catalytic Combustion of Methane in a Microcombustor with Metal Foam Monolithic Catalyst. Catalysts 2018, 8, 536. [CrossRef]

3. Gerasimov, E.Y.; Rogov, V.A.; Prosvirin, I.P.; Isupova, L.A.; Tsybulya, S.V. Microstructural Changes in $\mathrm{La}_{0.5} \mathrm{Ca}_{0.5} \mathrm{Mn}_{0.5} \mathrm{Fe}_{0.5} \mathrm{O}_{3}$ Solid Solutions under the Influence of Catalytic Reaction of Methane Combustion. Catalysts 2019, 9, 563. [CrossRef]

4. AlMohamadi, H.; Smith, K.J. The Impact of $\mathrm{CeO}_{2}$ Loading on the Activity and Stability of $\mathrm{PdO} / \gamma-\mathrm{AlOOH} / \gamma-\mathrm{Al}_{2} \mathrm{O}_{3}$ Monolith Catalysts for $\mathrm{CH}_{4}$ Oxidation. Catalysts 2019, 9, 557. [CrossRef]

5. Lenk, T.; Gärtner, A.; Stöwe, K.; Schwarz, T.; Breuer, C.; Kiemel, R.; Casu, S. A High-Throughput Screening Approach to Identify New Active and Long-Term Stable Catalysts for Total Oxidation of Methane from Gas-Fueled Lean-Burn Engines. Catalysts 2020, 10, 159. [CrossRef] 